\title{
Effects of pounding on the behavior of reinforced concrete frame structures in seismic zone 2B
}

\author{
Muhammad Hamid*, Fayyaz Ur Rahman and Qaisar Ali \\ * Department of Civil Engineering, University of Engineering and Technology, Peshawar, Pakistan \\ *Correspondent Author: hamid.uetian92@gmail.com
}

Submitted :08/07/2020

Revised : :15/10/2021

Accepted :26/10/2021

\begin{abstract}
Pounding between adjacent buildings is a common phenomenon, which can be observed during moderate to high ground shakings that can result in structural damage and even loss of life. As this phenomenon is related to the life safety, therefore, it is imperative to consider it in the modelling stage of structural analysis and design. The current study is intended to evaluate, numerically, the effect of pounding phenomenon in RC frame structures. Threedimensional models of two hypothetical buildings are analyzed by subjecting to three ground acceleration histories that are scaled and matched with BCP-SP07 design spectrum. The analysis results such as interstory drift, maximum displacement, pounding forces, and their effects on bending moment, axial forces, and shear and torsional forces in structural members are compared. The results show that pounding forces decrease with the increase in gap size and are dominant in top five stories with maximum force at the top floor level. Pounding increases displacement up to 2 times and acceleration up to 240 times as compared to the case without pounding. Pounding increases the axial forces up to 250 times and bending moment up to 2 times in the beams parallel to colliding forces. Similarly, the shear forces and torsional moments are almost doubled as a result of pounding. Finally, a 20-story building consists of four blocks separated by 3-inch expansion joints is modelled combinedly in ETABS and analyzed to see the effect of pounding. Based on the results, it is concluded that pounding must be considered at the modelling stage of the design to account for the forces induced in the structural members.
\end{abstract}

Keywords: Pounding phenomenon; RC frame structures; BCP SP-07; Design spectrum; ETABS.

\section{INTRODUCTION}

Due to the difference in dynamic properties, the relatively tall neighboring buildings can collide during ground shaking of moderate to high intensity. This phenomenon is known as structural pounding. Pounding induces additional forces in structural members at diaphragm level, which results in local crushing or even can cause collapse and ultimately loss of life. Therefore, it is necessary to consider pounding in structural analysis and design (BCPSP07; UBC-97; ACI 318-14; ASCE/SEI7-10; Raheem; Pokharel et al., Mouzakis and Papadrakakis, 2008).

In an extreme event, pounding can even lead to the collapse of structure (Shrestha and Hao, 2018; Ehab et al., 2014; Lin, 2005; Lin and Weng, 2011). In Figures 1 and 2, typical cases of ponding are shown (Shrestha and Hao, 
2018). During the 1985 Mexico earthquake, $40 \%$ of damaged structures experienced some level of pounding, and in $15 \%$ of the cases, pounding was identified as the primary reason for the structural collapse (Pawar and Murrnal, 2014).

More than 200 cases of pounding occurred during the Loma Prieta earthquake and the related collapse of some buildings (Kasi et al., 1992). Cole et al. (2010) attributed pounding to the reason for the severe damage of 6-12\% of the surveyed buildings in Christ-church Central Business District (CBD).

Behzad Fatahi et al. (2018) investigated the effect of separation gap on the seismic response of midrise buildings supported on piles while considering the soil-pile structure interaction (SSPSI). The buildings were excited by 1994 Northridge and 1995 Kobe earthquakes. The buildings were modelled in ABAQUS. The nonlinear behavior of structural elements was also included in the model. From the results, it was concluded that the minimum separation gap should be $1.75 \%$ of the total building height. Hytham Elwardany et al. (2017) investigated the effect of infill walls on the seismic pounding behavior of buildings in series. To get the said purpose, they conducted nonlinear finite element analyses on different infill configuration throughout the structure. From the results of analysis, it was concluded that infill can substantially change the seismic pounding behavior of the structure. Maria J. Favvata (2017) evaluated the seismic performance of real RC buildings against different separation gaps as per Eurocode 8. 882 nonlinear analyses were performed with scaled ground motions. The gap between the buildings was estimated for two cases. In case 1, the gap was estimated for considering the failure in the most critical column that suffers impact. In case 2, the complete avoidance of the buildings was considered. The results of this study were compared with the Eurocode 8 provisions, and it was found that the separation gaps calculated from this study are less conservative than the codal provisions. Robert Jankowski (2009) conducted a pounding study on the main building and stairway tower of the Olive View Hospital.

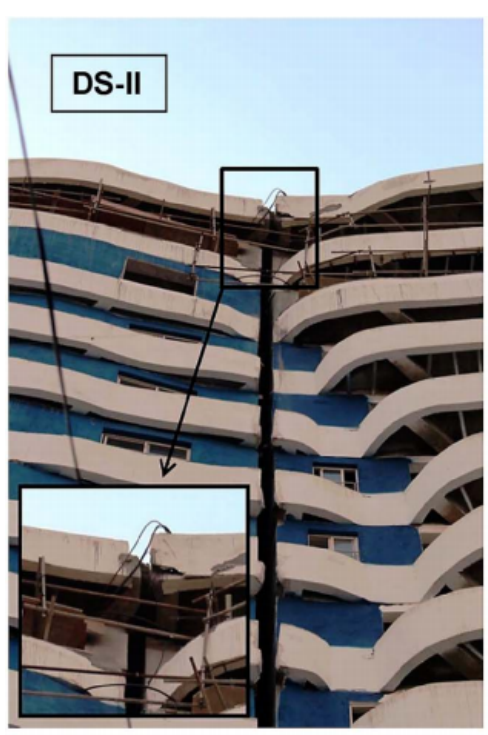

(a)

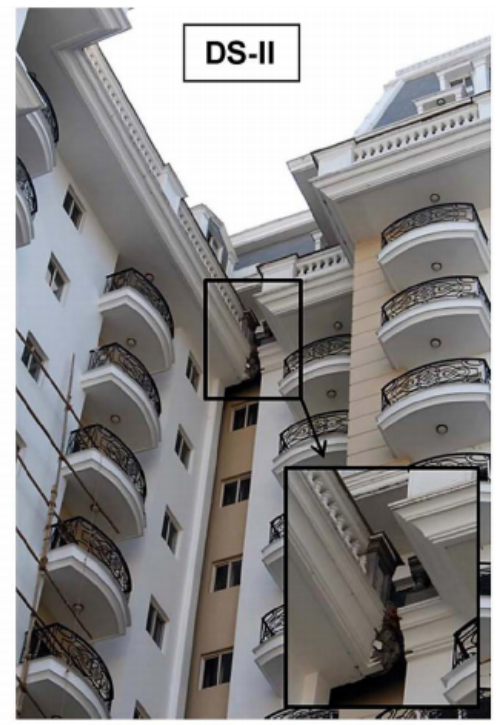

(b)

Figure 1. Typical cases of pounding in apartment buildings with wide separation:

(a) pounding between two blocks. (b) Pounding of projected roof cornices. 


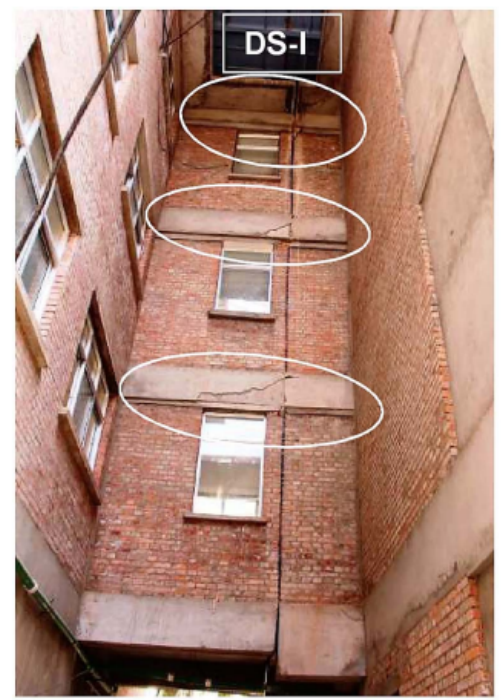

(a)

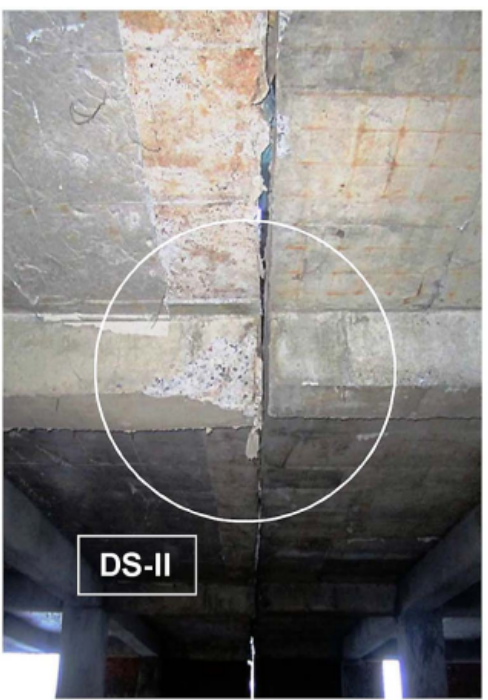

(b)

Figure 2. Typical cases of pounding in building with insufficient separation: (a) pounding between two blocks. (b) Pounding damage at beam.

Nonlinear analysis was carried out for two adjacent buildings. FEM was used for analysis. The results of the study reveal that the collision may increase the response of the light stairway building and also can increase the damage intensity and range at the base. The heavier main building had little effect due to the collision.

Deepak R. Pant and Anil C. Wijeyewwickrema (2011) conducted ponding studies on a typical four-story base isolated $\mathrm{RC}$ building. Three-dimensional finite element analyses were conducted considering geometric and material nonlinearities. It was concluded that the performance of the base isolated building is significantly influenced by the pounding. The base isolated building showed good performance against shear failure. Sofia Efraimiadou et al. (2013) investigated the effect different structural configurations on the collisions between RC building frames subjected to strong ground motions. Nine different arrangements were made from 5-story and 8-story frames. The pair of building is subjected to six ground motions compatible with design process. Various parameters were investigated such as ductility, internal forces, story displacements, and interstory drifts. From the results, it was concluded that collision is unfavorable for most of the cases. Harris P. Mouzakis and Manolis Papadrakakis (2014) investigated two adjacent buildings having aligned rigid horizontal diaphragms for linear and nonlinear structural response of pounding phenomenon. The three-dimensional dynamic contact conditions for the velocity and acceleration were considered. The results were compared with the Lagrange multipliers approach. The elastic and inelastic structural responses were also taken into account. From this study, it was concluded that the formulation presented, as compared to the Lagrange multipliers approach, is computationally more efficient as it can be easily incorporated into existing computer codes for elastic and inelastic dynamic analysis of buildings. Most of the recent seismic codes suggest the provision of sufficient seismic joints for the seismic pounding mitigation (Xue et al., 2016; NZS 1170.5, 2004; Eurocode 8; IS. 1893.1984 Indian Standards). For example, the National Earthquake Hazard Reduction Program (NEHRP) of USA states in section C12.12.3 states that "this standard does not give a precise formulation for the separations, but it does require that the distance be sufficient to avoid damaging contact under total deflection." It is recommended that the distance be no less than the square root of the sum of the squares of the lateral deflections, which represent the anticipated maximum inelastic deformations including torsion, of the two units assumed to deflect toward each other. Similarly, UBC-97 1633.2.11 states that all structures shall be separated from adjoining structures. Separation shall be calculated as per Equation 1. 


$$
\Delta_{M T}=\sqrt{\left(\Delta_{M 1}\right)^{2}+\left(\Delta_{M 2}\right)^{2}}
$$

$\Delta_{M 1}$ and $\Delta_{M 2}$ are the displacements of the adjacent buildins.

The trend of high-rise buildings in metropolitan cities of Pakistan is increasing day by day. Due to the high cost and limited availability of land, most of the new buildings are constructed adjacent to each other, thus increasing the vulnerability of the building stock to structural pounding. The aim of this study is to evaluate the response of buildings subjected to pounding phenomenon for high rise buildings constructed in Zone 2B as per BCP-SP07. In this regard, two hypothetical RC frame buildings having unequal heights are analyzed using ETABS v17, for pounding induced effects. A real building case study was also carried out.

\section{METHODOLOGY}

The current study is conducted in order to evaluate, numerically, the effect of pounding phenomenon in RC frame structures for seismic Zone 2B as per BCP-SP07 building code of Pakistan. Three-dimensional models of two hypothetical buildings are analyzed in finite element software ETABS, and the pounding effect is captured through nonlinear gap elements. These buildings are analyzed using nonlinear modal time histories as per BCP-SP07. Three ground acceleration histories are selected, scaled, and matched with BCP-SP07 design spectrum using SeismoSoft package "SeismoMatch." The analysis results such as interstory drift, maximum displacement, pounding forces, and their effects on bending moment, axial forces, shear, and torsional forces in structural members are compared.

\section{BUILDING DESCRIPTION}

Two hypothetical buildings of unequal heights are taken and named as taller building and shorter building. The taller building has 15 stories (Height=180 ft) and 4 bays in $\mathrm{x}$ - and y-directions. The column size is 36 -inch x 36 -inch, and beam size is 15 -inch $\times 24$-inch. Slab thickness is taken as 7.5 inches. The shorter building has 12 stories (Height $=144 \mathrm{ft}$ ) and 4 bays in $\mathrm{x}$ - and y-directions. The column size is 30-inch x 30-inch, and beam size is 15-inch x 24-inch. Slab thickness is taken as 7.5 inches. The plan and elevation of taller and shorter building are shown in Figures 3 and 4.

\section{GAP ELEMENT}

Various link elements with different properties are available in define menu of ETABS. However, the gap element is used for the current study. Pounding can be simulated by gap (ETABS: analysis reference manual). It is a compression member only. The separation between the buildings is defined as a gap. The gap element gives axial force when the gap is closed. The gap uses nonlinear force deformation relationship as shown in Equation 2.

$$
f=\left\{\begin{array}{c}
K(d-\text { open }) \\
0
\end{array}\right\} \begin{gathered}
\text { if } d-\text { open }<0 \\
\text { otherwise }
\end{gathered}
$$

where $\mathrm{d}$ denotes displacement, open is the initial gap opening, which must be zero or positive, and $\mathrm{k}$ is the stiffness of the element. The stiffness of the gap element should be 100 times greater than the axial stiffness of the connected members (ETABS: analysis reference manual). The stiffness of gap element can be determined from Equations 3 and 4. "E" is the modulus of elasticity, "A" is the cross-sectional area of the connected members, and L 
is the length of the connected members. EA/L is the axial stiffness of the connected members. As per Equations 3 and 4, the stiffness for the current study comes out to be $390250 \mathrm{kip} / \mathrm{in}$.

$$
K=\frac{E A}{L} \times 100
$$

$$
K=\frac{\text { Modulus of elasticity of concrete } \times \text { Area of contact surface }}{\text { Length of element of contact surface }} \times 100
$$

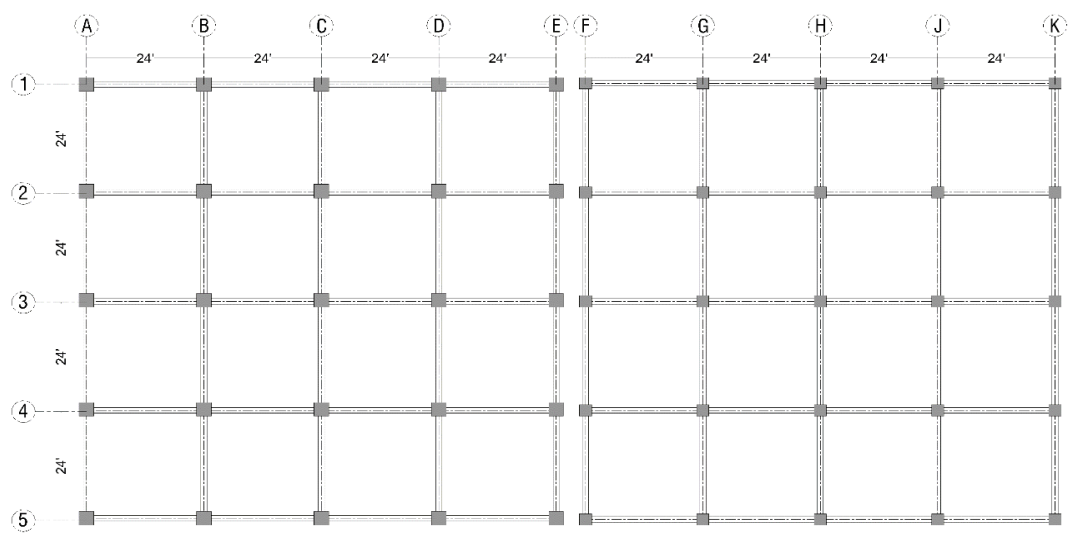

Figure 3. Plan view of taller building (left side) and shorter building (right side).

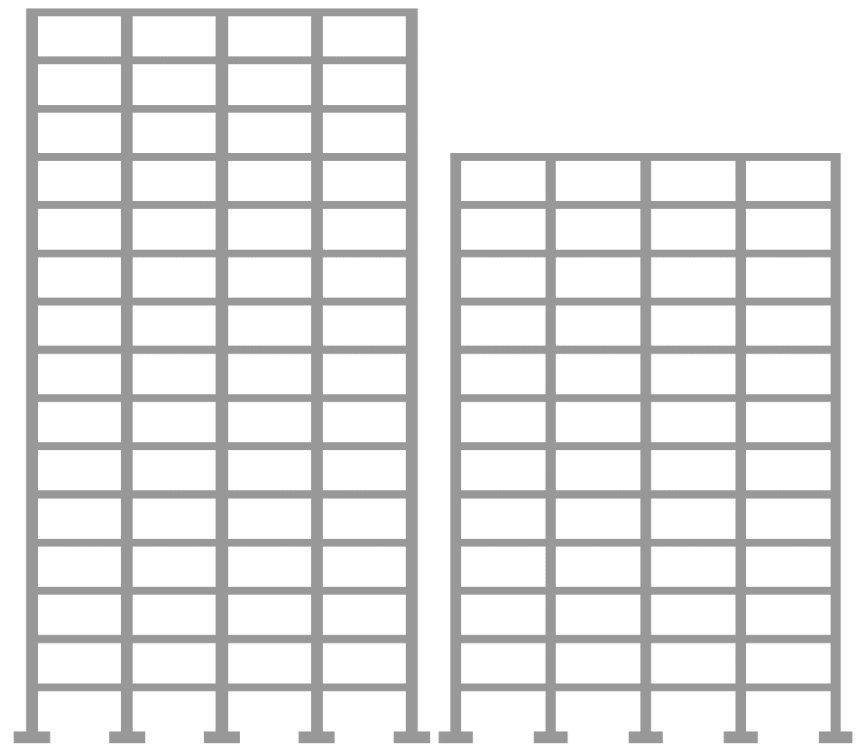

Figure 4. Elevation of taller (left side) and shorter building (right side). 


\section{DESIGN LOADS}

Dead loads consist of self-weight of structural members and superimposed dead loads. ETABS calculates selfweight of structural member from their respective unit weights of materials. Uniformly distributed load of $40 \mathrm{psf}$ for 3.5" thick P.C.C and 60 psf for solid brick masonry walls has been considered on all floors. Live load consists of 40 psf for all floors except roof for which $20 \mathrm{psf}$ load is considered as per Table 4-1 of ASCE7-10.

\section{EARTHQUAKE ANALYSIS OF BUILDINGS}

Earthquake loads are defined as per BCP-SP07 chapter 5 Division IV. Preliminary analysis is carried out using static lateral force procedure in order to calculate the static base shear and time period corresponding to fundamental mode. The earthquake load parameters are summarized in Table 1. The soil type is chosen as Type-D as per section 4.4 of BCP-SP07. The response modification factor $\mathrm{R}$ is taken as 8.5 for SMRF.

Table 1. Lateral Load Parameters.

\begin{tabular}{|c|c|c|}
\hline S. No. & \multicolumn{2}{|c|}{ Earthquake Load Parameters } \\
\hline 1 & Seismic Zone Factor & 0.2 \\
\hline 2 & BCP-SP07 Soil Type & Type-D \\
\hline 3 & Importance Factor & 1.00 \\
\hline 4 & Response Modification Factor, R & 8.5 \\
\hline 5 & Mass Source & Self-Weight + Super Imposed Dead Loads \\
\hline
\end{tabular}

\section{GROUND MOTION RECORDS FOR DYNAMIC ANALYSES}

Three ground motions obtained from PEER strong motion database are used for dynamic analyses. The ground motions are scaled with the design spectrum of BCP-SP07/ UBC-97. For scaling purpose, SeismoMatch software is used. The scaled ground motions are then normalized with static base shear, calculated as per static lateral force procedure given in section 5.30.2 of BCP -SP07

\section{RESULTS AND DISCUSSION}

The analysis results for both pounding and without pounding cases are discussed in this section. The effect of different gap sizes (opening between adjacent buildings/seismic joint) on the pounding forces is studied first to determine the appropriate seismic joint between the two adjacent buildings. However, it is a normal practice in the construction industry of Pakistan to provide two-inch expansion joint between different blocks of the same building; therefore, it is necessary to investigate the effect of pounding between two adjacent buildings separated with twoinch expansion joint. In the first part, the effects of pounding on pounding forces, modal frequencies, spectral displacements, and spectral accelerations are evaluated for two hypothetical buildings, and these buildings are analyzed as per BCP-SP07 considering the effect of pounding. In the second part, a real building case study is discussed, and the effect of pounding on its analysis is presented. 


\section{EFFECT OF GAP SIZE/ SEISMIC JOINT ON POUNDING FORCE}

The effect of gap size on the pounding forces at top floor of 12-story building is compared in Table 2 for Kobe ground motion. It is clear from the results that the pounding force increases as the gap size increases from 2 to 4 inches. The reason for this increase is that the 4-inch gap is insufficient for the most severe contact between the buildings. Further increase in gap size decreases the pounding force, and the decrease for 6 inches gap size is almost $42.12 \%$ less as compared to the pounding force corresponding to 2-inch gap. The pounding force for 8-inch gap is $71 \%$ less than the pounding force corresponding to 2 in gap size pounding force. From these results, it is worth mentioning that enough gap distance shall be provided between the buildings, or the buildings shall be designed for pounding forces in order to avoid damage to the structural members or even collapse of the complete building.

Table 2. Gap size versus average pounding force.

\begin{tabular}{|c|c|c|}
\hline $\begin{array}{c}\text { Gap Size/ Seismic joint } \\
\text { (inch) }\end{array}$ & $\begin{array}{c}\text { Time } \\
\text { (sec) }\end{array}$ & $\begin{array}{c}\text { Average Pounding Force } \\
\text { (kip) }\end{array}$ \\
\hline 2 & 17.49 & 4067 \\
\hline 4 & 20.35 & 4863 \\
\hline 6 & 27.34 & 2352 \\
\hline 8 & 23.8 & 1166 \\
\hline
\end{tabular}

\section{POUNDING FORCES}

The pounding induces additional forces at different story levels. Figure 5 shows that maximum pounding force occurs at $12^{\text {th }}$ story floor level, and it decreases from top to bottom, and its value gets zero at $5^{\text {th }}$ story floor level. It is worth mentioning that the pounding force at top stories is of such a large magnitude that it can cause severe damage to the structural members and, therefore, must be considered in the design of structural members.

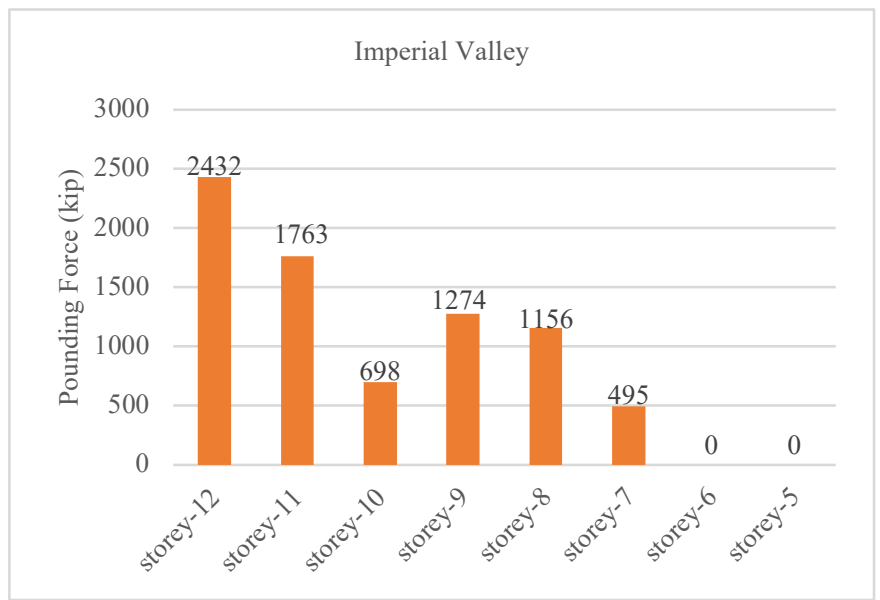

Figure 5a. Imperial Valley 


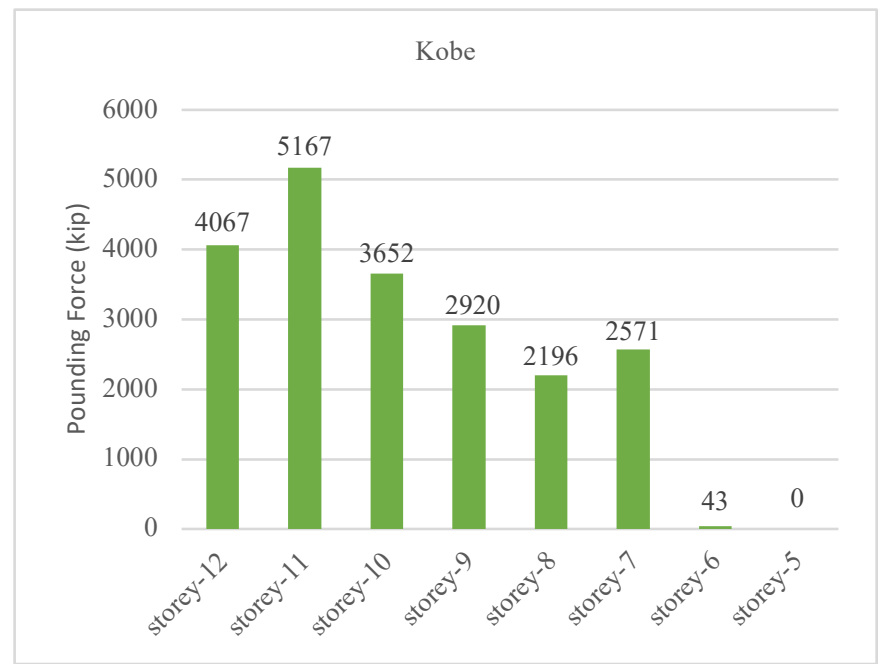

Figure 5b. Kobe

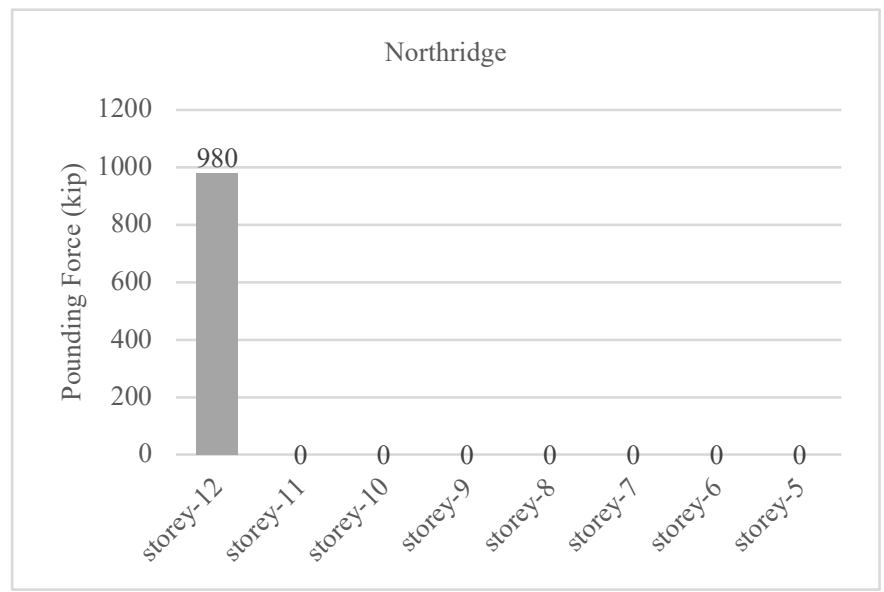

Figure 5c. Northridge

Figure 5. Pounding force comparison.

\section{EFFECT ON THE ACCELERATION OF BUILDINGS SUBJECTED TO POUNDING}

Pounding induces significant acceleration at impact locations generating large impact forces in both shorter and taller building. Spectral acceleration response histories for taller and shorter building at pounding level are shown in Figures 6 and 7. In Figure 6, acceleration response history for Imperial Valley shows vigorous changes in spectral acceleration for both positive and negative acceleration values. The maximum value of acceleration for pounding case is $-12000 \mathrm{in} / \mathrm{sec} 2$ at 13.49 seconds where, without pounding case, the maximum value is just $-49.75 \mathrm{in} / \mathrm{sec} 2$ at 10.48 seconds. The magnitude of acceleration for pounding case is almost 240 times more than that without pounding case. Almost similar results are shown in Figure 7 for shorter building. 

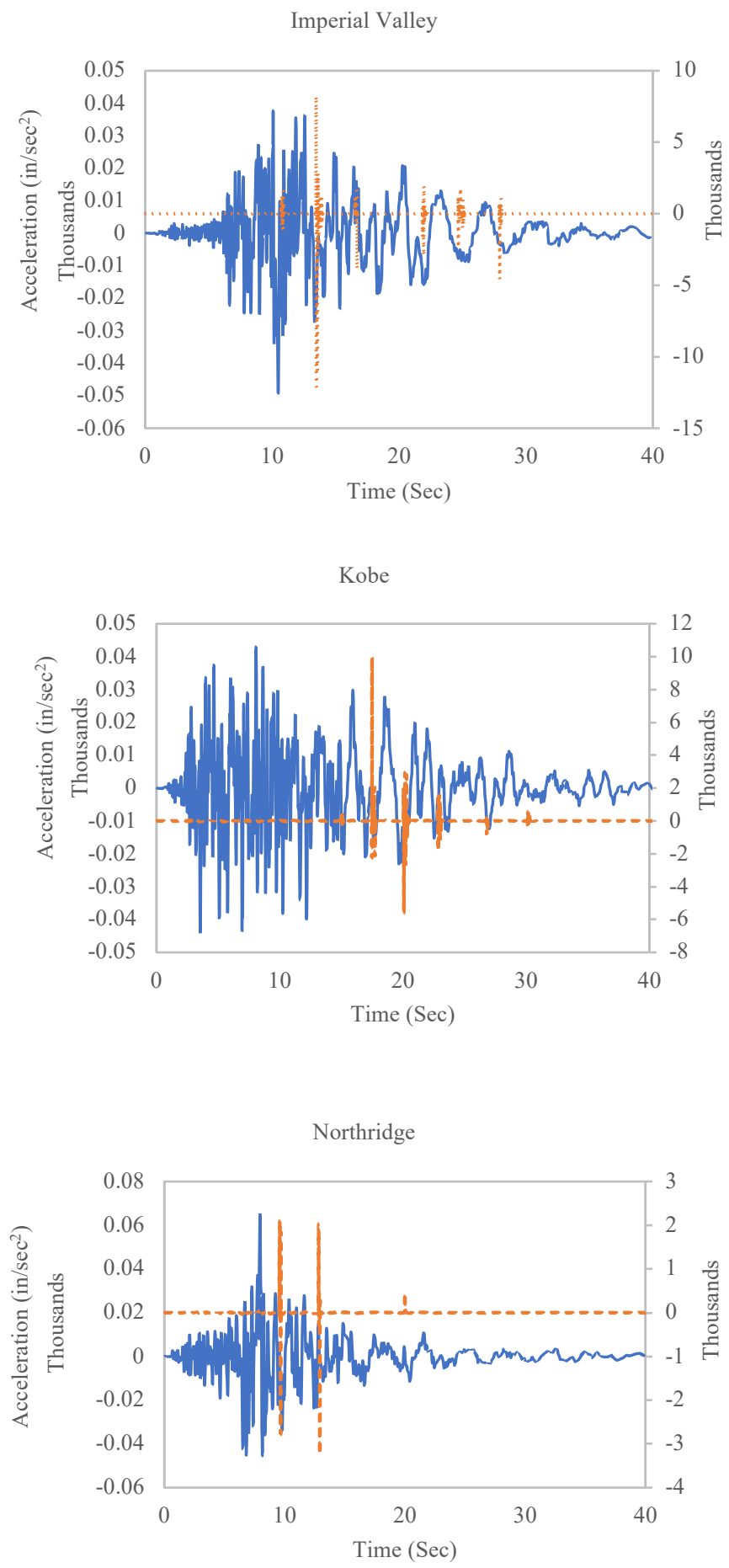

Without Pounding Case

- Pounding Case

Figure 6. Acceleration history of taller building at pounding level. 

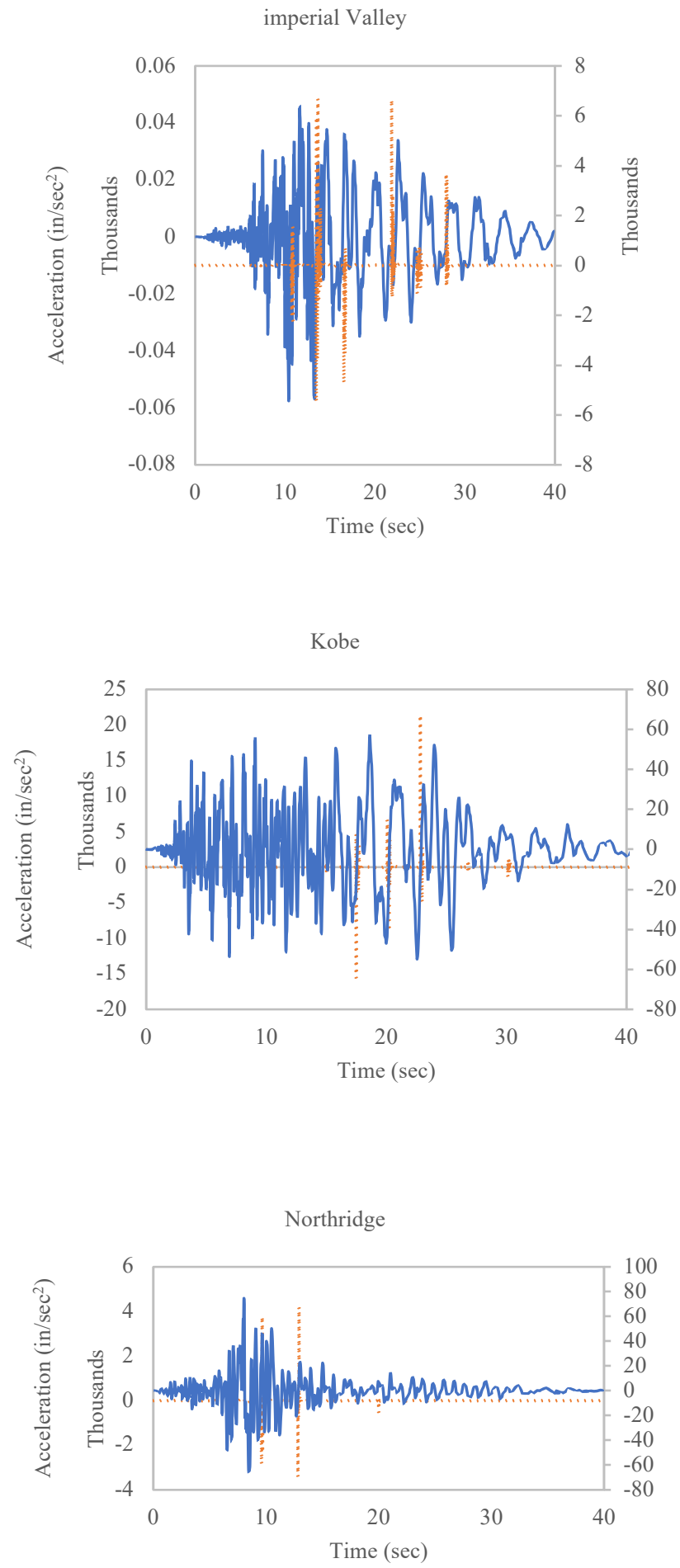

Pounding Case Without Pounding Case

Figure 7. Acceleration history of shorter building at pounding level. 


\section{EFFECT ON THE BENDING MOMENT, AXIAL FORCE, SHEAR FORCE, AND TORSION OF BUILDINGS SUBJECTED TO POUNDING}

Figure 15 shows typical beam-column plan of the two buildings. Beams named as B1, B2, B3, and B4 are clearly marked on the plan for which the values of bending moment, axial force, shear force, and torsional moment are compared in Table 5, and in Figures 8, 9, and 10, major response diagrams are shown. Table 3 shows that bending moments in pounding case increase by 1.5 to 2 times as compared to that without pounding case. Similarly, a tremendous increase in the axial forces for the pounding case, as the impact forces developed are directly carried out by these beams, is also shown in Table 3. The axial compression forces increased up to 250 times and axial tension forces increased by 50 to 100 times in case of pounding as compared to those without pounding case. Shear forces and torsional moments are almost doubled in case of pounding as compared to those without pounding case.

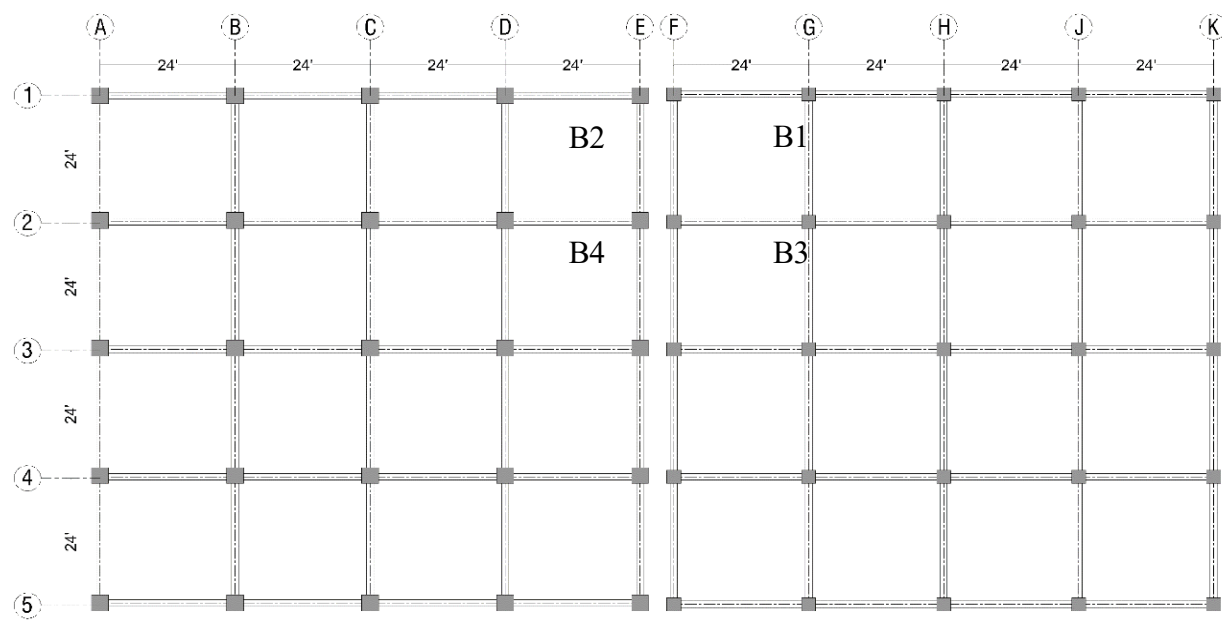

Figure 8. Plan view of taller building (left side) and shorter building (right side).

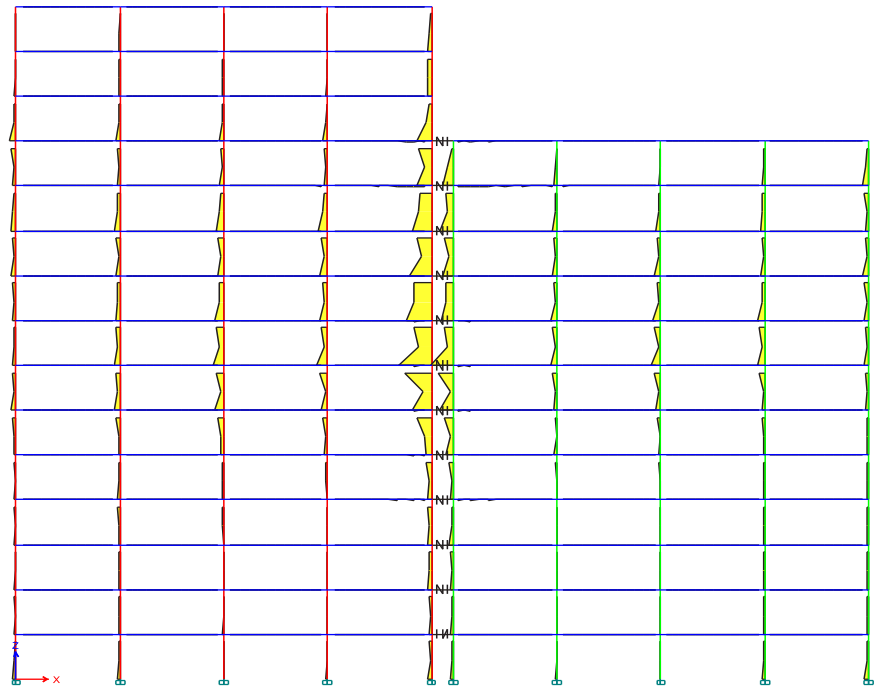

Figure 9. Torsional moment diagram of pounding Case (Elevation View). 


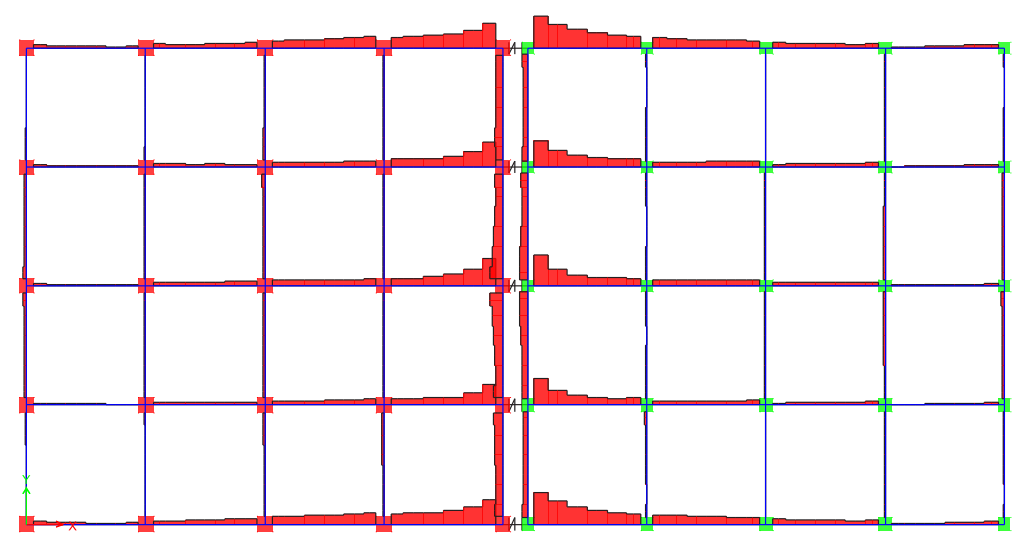

Figure 10. Axial force (Compression) diagram of pounding (Plan View).

Table 3. Comparison of Shear force, bending moment, and torsion.

\begin{tabular}{|c|c|c|c|c|c|c|c|c|}
\hline & \multicolumn{4}{|c|}{ Without pounding case } & \multicolumn{3}{c|}{ pounding case } \\
\cline { 2 - 9 } $\begin{array}{c}\text { Beam } \\
\text { ID }\end{array}$ & $\begin{array}{c}\text { Shear } \\
\text { (kip) }\end{array}$ & $\begin{array}{c}\text { Torsion } \\
\text { (kip-ft) }\end{array}$ & $\begin{array}{c}\text { Moment } \\
\text { (kip-ft) }\end{array}$ & $\begin{array}{c}\text { Axial } \\
\text { force } \\
\text { (kip) }\end{array}$ & $\begin{array}{c}\text { Shear } \\
\text { (kip) }\end{array}$ & $\begin{array}{c}\text { Torsion } \\
\text { (kip-ft) }\end{array}$ & $\begin{array}{c}\text { Moment } \\
\text { (kip-ft) }\end{array}$ & $\begin{array}{c}\text { Axial force } \\
\text { (kip) }\end{array}$ \\
\hline B1 & 6.8 & 1.2 & 56 & 3 & 13 & 2.5 & 112 & 254 \\
\hline B2 & 14.5 & 2.5 & 94 & 1.6 & 18 & 3.5 & 148 & 200 \\
\hline B3 & 9.2 & 0.02 & 58 & 1.1 & 19 & 0.5 & 122 & 214 \\
\hline B4 & 20.3 & 0.009 & 98 & 1.3 & 26 & 0.2 & 156 & 197 \\
\hline
\end{tabular}

\section{REAL BUILDING STUDY}

The building named as "dominion mall and apartments" situated at Bahria Town Rawalpindi is considered as a case study for the pounding analysis. The building is a twenty-story reinforced concrete frame structure. The ETABS 3D model and typical beam column plan of the building are shown in Figures 11 and 12. The analysis procedure used for the hypothetical buildings is carried out for this case study. The pounding force comparison for dominant ground motions is shown in Figure 13. 


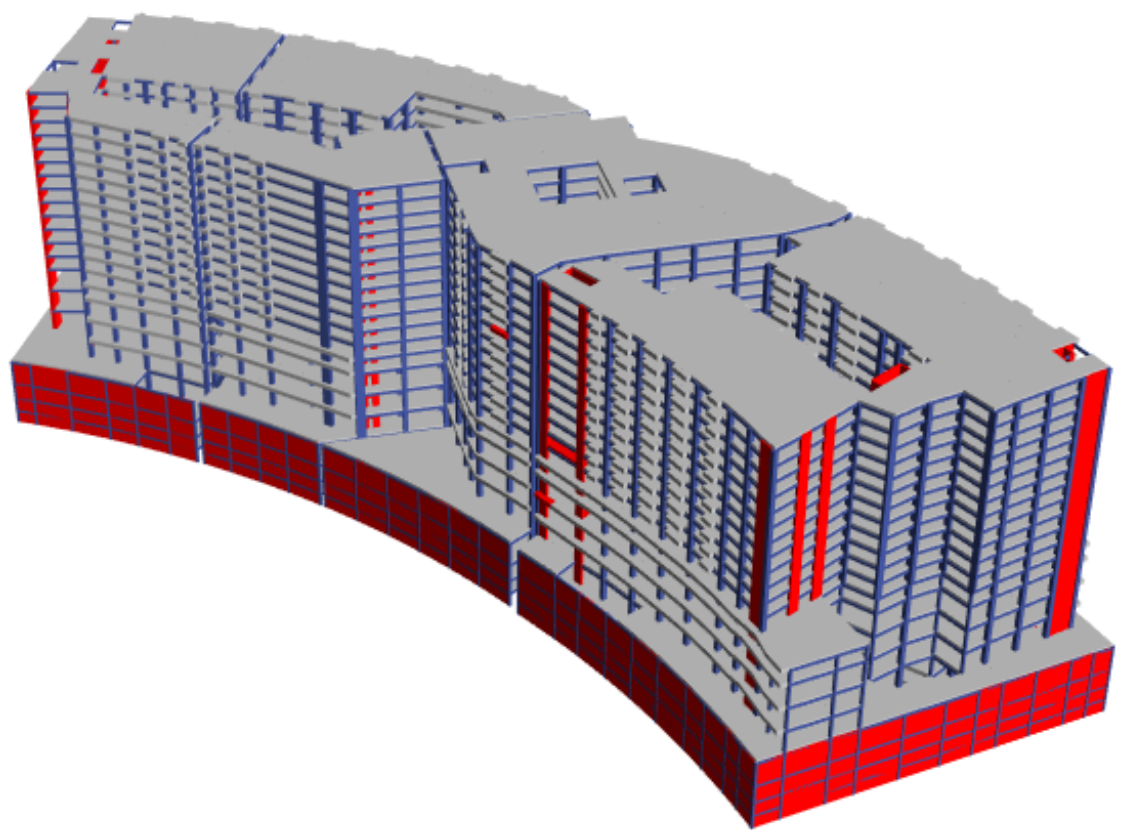

Figure 11. ETABS model of Dominion Mall \& Apartments.

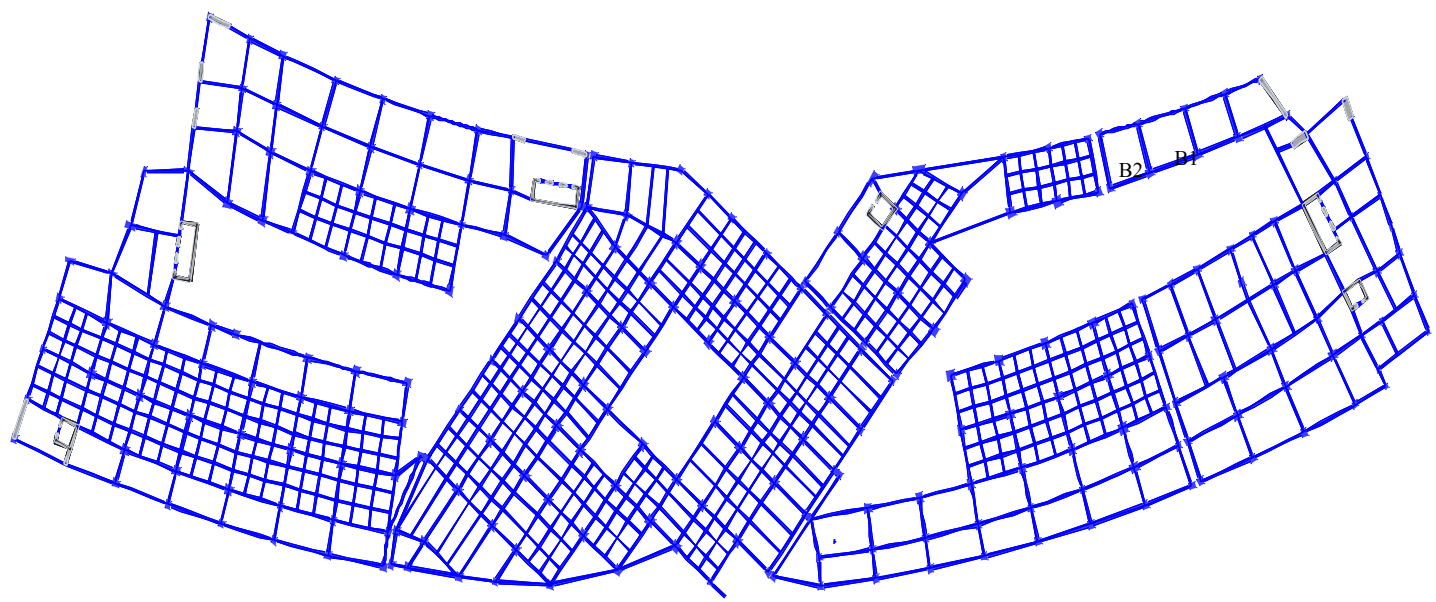

Figure 12. Typical beam-column plan. 

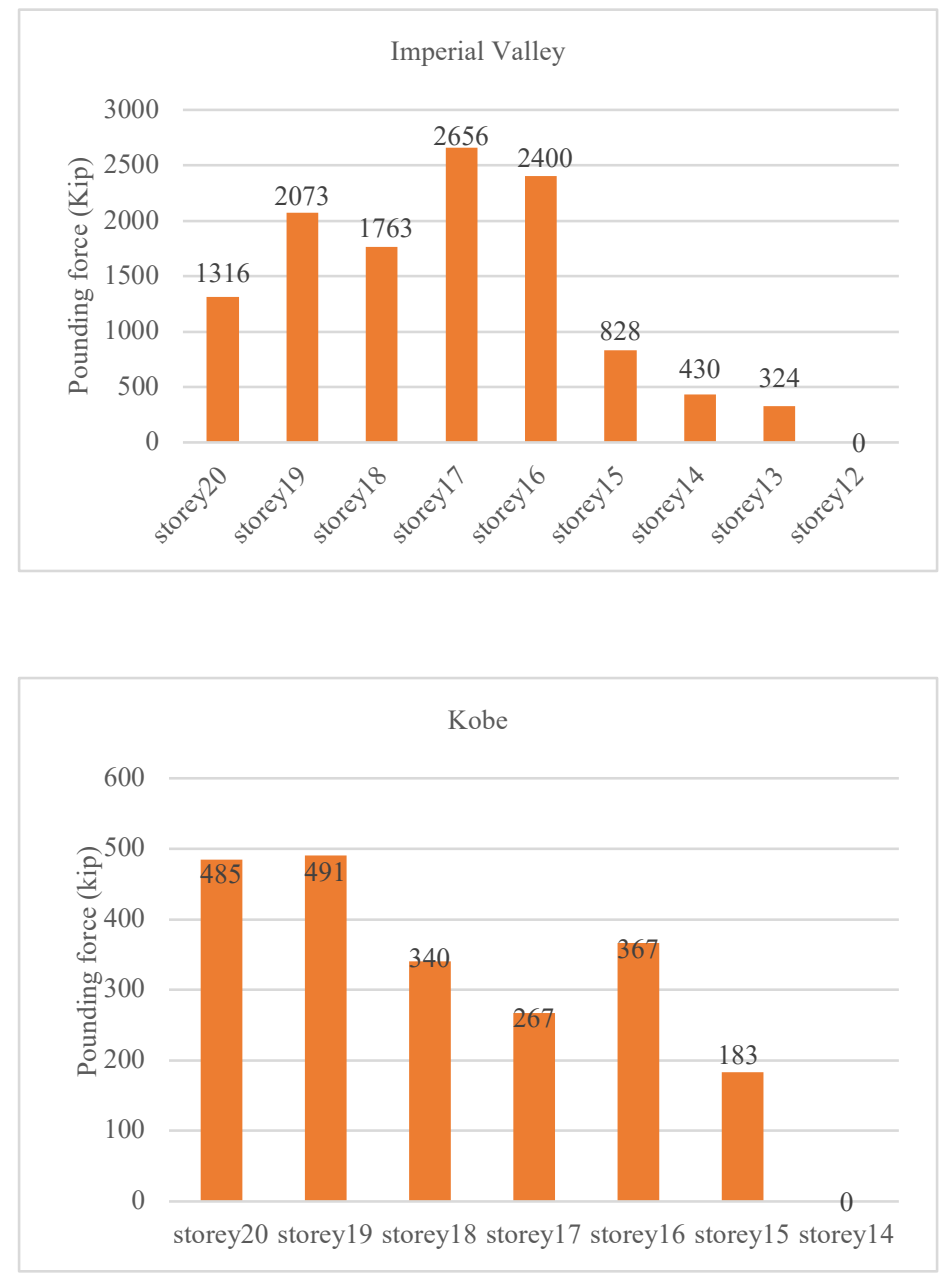

Figure 13. Pounding force comparison.

The variation in bending moment, axil force, shear force, and torsion in the real building case study is almost similar to the results shown in Table 3.

\section{CONCLUSIONS}

Based on the results of this study, the following conclusions are drawn.

- The gap size has dominant effect on the magnitude of pounding forces. Sufficient gap size can reduce pounding forces from buildings, and hence, the gap size suggested by the BCP-SP07 must be at least provided. However, a 2-inch to 3-inch expansion joint is normally provided between different blocks of the same building, which is not a sufficient seismic gap especially for high rise buildings. Therefore, pounding analysis must be carried out for such buildings. However, for hypothetical buildings considered in this study, a 6-inch gap size is recommended.

- Pounding substantially increases the spectral acceleration up to 240 times for the considered case study.

- Pounding increases shear force, bending moment, and torsional moment, and there is a tremendous increase up to 250 times in the axial forces. Moreover, it places additional torsional demand on the columns subjected to pounding. 
- $\quad$ The induced pounding forces have large magnitudes, which can damage the structural members; especially they can cause crushing at diaphragms due to the hammering action of the pounding forces.

- The pounding forces are significant at top stories and decrease from top to bottom. The forces are much lesser at bottom stories.

\section{REFERENCES}

ACI 318-14. Building code requirements for structural concrete 2014.

ASCE/SEI7-10. Minimum design loads for buildings and other structures 2010.

BCP-SP07. Building code of Pakistan seismic provisions 2007. Technical Document, Ministry of Housing and Works, Islamabad.

Cole, G, L., Carr, D, A, J. and Bull, D, K. 2010. Identifying structures vulnerable to pounding damage. 2010, NZEEE Conference.

Dogan, M., Gunaydin, A. 2009. Pounding of Adjacent Buildings During Seismic Loads. Journal of Engineering and Architecture Vol: XXXII, No: 1, 2009.

Efraimiadou, S., Hatzigeorgiou, G. and Beskos, D. 2013. Structural pounding between adjacent buildings subjected to strong ground motions. Part I: The effect of different structures arrangement. Earthquake Engineering \& Structural Dynamics 2013, 42: 1509-1528.

Ehab, M., Salem, H. and Mostafa, H. 2014. Earthquake pounding effect on adjacent reinforced concrete buildings. International Journal of Computer applications. Volume 106-No.9.

Elwardany, H., Saleemah, Ayman. And Jankowski, R. 2017. Seismic pounding behavior of multi-storey buildings in series considering the effect of infill panels. Engineering Structures 144 (2017), 139-150.

ETABS. Analysis reference manual.

Eurocode 8. Design of structures for Earthquake resistance.

Fatahi, B., Nguyen, V, Q., Xu, R. and Sun, W. 2018. Three-Dimensional Response of Neighboring Buildings Sitting on Pile Foundations to Seismic Pounding. 10.1061/(ASCE)GM.1943-5622.0001093.

Favvata, Maria. 2017. Minimum Required Separation gap for adjacent RC frames with potential inter-story seismic pounding. Engineering Structures 152 (2017), 643-659.

Hao, H. 2015. Analysis of seismic pounding between adjacent buildings. Australian Journal of Structural Engineering. Vol. 16, No. 3, 208-225.

IS. 1893.1984 Indian Standards. Criteria for Earthquake resistant design of structures.

Jameel, M., Islam, A, B, M., Hussain, R, R., Hassan, S, D., Khaleel, M. 2013. Non-linear FEM Analysis of seismic induced pounding between neighboring Multi-storey Structures. Latin American Journal of Solids and Structures. 10(2013), 921-930.

Jankowski, R. 2009. Non-linear FEM analysis of earthquake-induced pounding between the main building and the stairway tower of the Olive View Hospital. Engineering Structures 31 (2009), 1851-1864.

Kasi, K., Jeng, V., Patel, P, C. and Munshi, J, A. 1992. Seismic pounding effects-Survey and analysis. Earthquake Engineering. Tenth World Conference, ISBN 9054100605.

Lin, J, H. Evaluation of seismic pounding risk of buildings in Taiwan. Journal of the Chinese institute of Engineers. Vol. 28, No. 5, pp. 867-872 (2005).

Lin, J, H. and weng, C, C. 2011. A study on seismic pounding probability of buildings in Taipei metropolitan area. Journal of Chinese institute of Engineers. 37-41. 
Mouzakis, H, P. and Papadrakakis, M. 2014. Three-dimensional non-linear building pounding with friction during earthquakes. Journal of Earthquake Engineering 1072954, 37-41.

Mouzakis, H, P. and Papadrakakis, M. 2008. Three-dimensional nonlinear building pounding with friction during Earthquakes. Journal of Earthquake Engineering. 1072954, 37-41.

NEHARP. National Earthquake hazard reduction program of USA

NZS 1170.5-2004. New Zealand Seismic Regulations, Earthquake actions.

Pant, D. and Wijeyewickrema, A. 2011. Structural performance of a base-isolated reinforced concrete building subjected to seismic pounding, Earthquake Engineering and Structural Dynamics 10.1002/eqe.2158.

Pawar, P. D. and Murnal, P, B. 2014. Effect of seismic pounding on adjacent blocks of unsymmetrical buildings considering soil-structure Interaction. International Journal of Engineering Technology and advanced Engineering. Volume 4, Issue 7, July 2014.

Pokharel, T. and Goldsworth, H, M. 2017. Lessons learned from the Nepal earthquake 2015. Australian Journal of Structural Engineering. 10.1080/13287982.2017.1309818.

Raheem, S, E, A. Mitigation measures for seismic pounding effects on adjacent buildings responses. COMPDYN, 12-14.

Shrestha, B. and Hao, H. 2018. Building Pounding Damages Observed during the 2015 Gorkha Earthquake. 10.1061/(ASCE)CF.1943-5509.0001134.

UBC-97. Uniform building code 1997.

Xue, Q., et al. 2016. An Updated Analytical Structural pounding force model based on viscoelasticity of Materials. Hindawi publishing Corporation Shock and Vibration Volume 2016. Article ID 2596923. 15 pages. [International Building code 2015]. 